\title{
THE ARTIFICIAL USE OF THE BROWN-TAIL FUNGUS IN MASSACHUSETTS
}

\author{
WITH PRACTICAL SUGGESTIONS FOR \\ PRIVATE EXPERIMENT, AND A BRIEF \\ NOTE ON A FUNGOUS DISEASE OF \\ THE GYPSY CATERPILLAR
}

BY A. T. SPEARE, ASSISTANT PATHOLOGIST HAWAIIAN SUGAR PLANTERS' ASSOCIATION AND R. H. COLLEY, aUSTIN TEACHING FELLOW IN BOTANY, HARVARD UNIVERSITY

UNDER THE DIRECTION OF

F. W. RANE, STATE FORESTER OF MASSACHUSETTS

BOSTON: WRIGHT \& POTTER PRINTING COMPANY STATE PRINTERS - - 18 POST OFFIGE SQUARE 1912 


PLATE I.

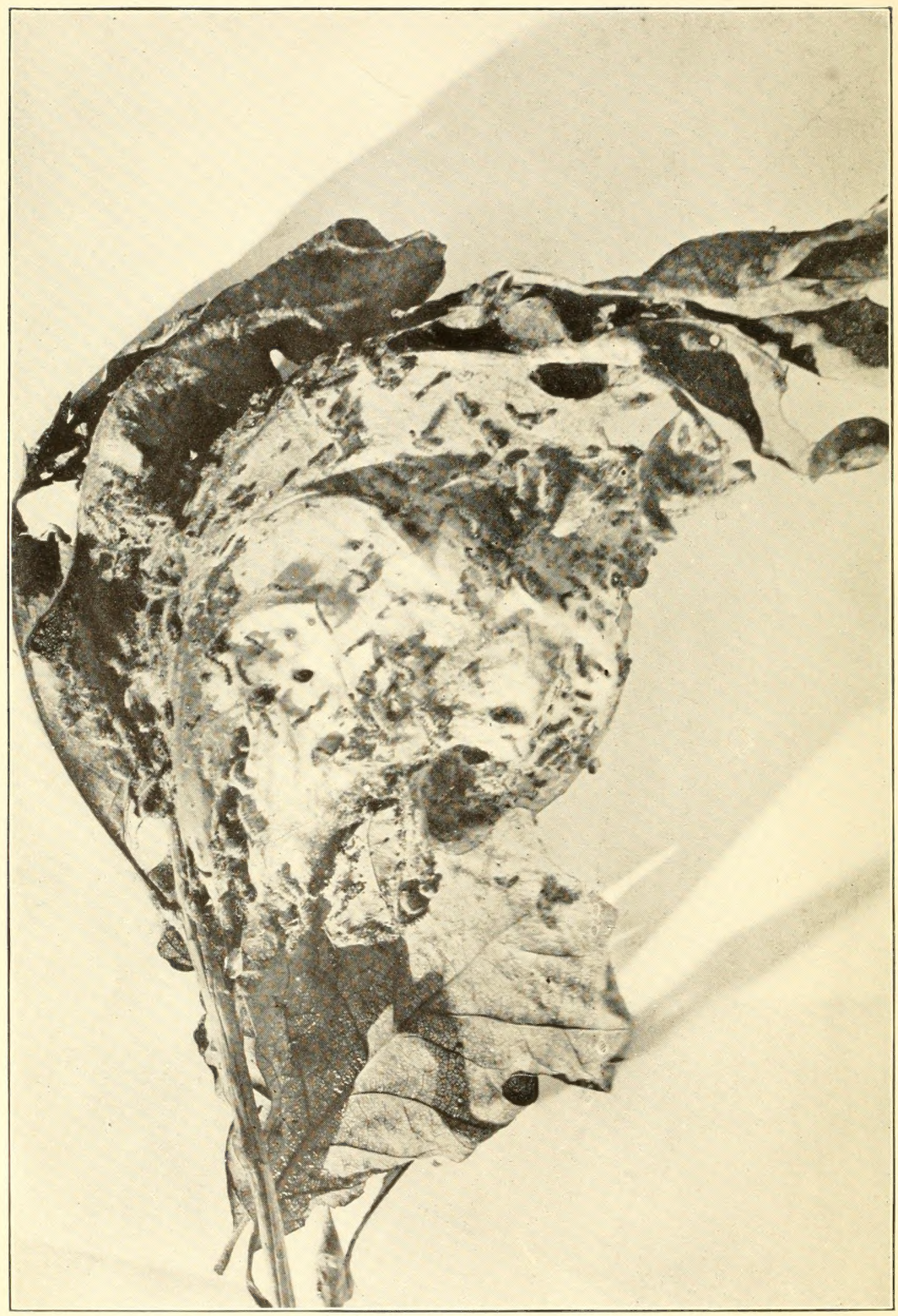

A winter nest with young larve dead from the disease scattered all over the surface. 


\title{
THE ARTIFICIAL USE OF THE
}

\section{BROWN-TAIL FUNGUS}

\section{IN MASSACHUSETTS}

\author{
WITH PRACTICAL SUGGESTIONS FOR \\ PRIVATE EXPERIMENT, AND A BRIEF \\ NOTE ON A FUNGOUS DISEASE OF \\ THE GYPSY CATERPILLAR
}

By A. T. SPEARE, assistant Pathologist HAWAIIAN SUGAR PLANTERS' ASSOCIATION and R. H. COLLEY, aUstin teaching FELLOW IN BOTANY, HARVARD UNIVERSITY

UNDER THE DIRECTION OF

F. W. RANE, STATE FORESTER

OF MASSACHUSETTS

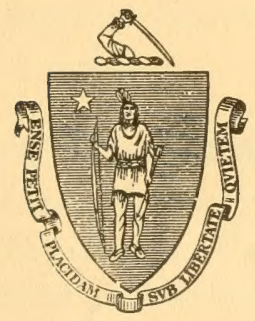

BOSTON: WRIGHT \& POTTER PRINTING COMPANY STATE PRINTERS

18 POST OFFICE SQUARE 


\section{SB945 B9M3 Cotpy 2 .}

by unsura

\section{OCT 30 M912}

APPROVED BT

The State Board of Publication. 


\section{INTRODUCTORY.}

This report is published in order to acquaint our people with the beneficial results to be derived from utilizing a fungous disease in destroying the brown'ttail möoth, which is so destructive to our deciduous trees and also so obnoxious to our people on account of the rash incident upon the contact of its hairs with the human skin.

The report is based on a manuscript of Dr. G. P. Clinton, on the manuscript and notes of Mr. A. T. Speare and on personal observation and experiment by Mr. R. H. Colley, and was suggested by the apparent success of experiments made by Dr. Roland Thaxter of Harvard University at Kittery Point, Me., in the summer of $1907 .{ }^{1}$ At this time former Superintendent Kirkland of the Moth Commission became interested in the matter, and on the advice of Dr. Thaxter the services of Dr. G. P. Clinton of the New Haven Agricultural Experiment Station were secured, and preliminary experiments were continued under his supervision from May 12 to July 11, 1908. Dr. Clintoll was assisted during June and July by Mr. A. T. Speare, who was later employed permanently by the State Forester to succeed Dr. Clinton, and who had immediate charge of the investigation from July, 1908, until February, 1911, while during the past year it has been in charge of $\mathrm{Mr}$. R. H. Colley. All of the laboratory experiments connected with this work have been conducted in the cryptogamic laboratories or at the Botanic Garden of Harvard University.

\section{ACKNOWLEDGMENTS.}

The State Forester and all concerned in the work wish to acknowledge their indebtedness to Professor Thaxter for suggestions as to experimental methods and for general direction and advice. Through the courtesy of Dr. G. L. Goodale and Mr. Oakes Ames, the directors of the Botanic Gardens, the successful propagation of the disease through the winter and the 
preparation of infection material on a large scale, have been rendered possible.

Thanks are also due Mr. Worthley, assistant in moth work, Messrs. Fiske and Burgess of the parasitic laboratory at Melrose Highlands, and to the division and local superintendents of the regular moth staff for their co-operation, and for courtesies rendered.

For the work on the fungus of the gypsy caterpillar, which has not as yet developed so satisfactorily as that on the browntail, we are wholly indebted to Harvard University through its friends in financing the expedition to Japan, where the disease was secured. The kindly offices of Harvard University, through Dean Sabine and his colleagues in assisting the State Forester in making this work possible, are herewith heartily acknowledged.

Boston, March 22, 1912.

F. W. RANE, State Forester. 
THE ARTIFICIAL USE OF THE BROWN-TAIL FUNGUS IN MASSACHUSETTS, WITH PRACTICAL SUGGESTIONS FOR PRIVATE EXPERIMENT, AND A BRIEF NOTE ON A FUNGOUS DISEASE OF THE GYPSY CATERPILLAR.

\section{SOME FUNGOUS DISEASES WHICH HAVE BEEN USED ARTIFICIALLY.}

The conditions governing the artificial spread of a fungous disease among insects vary according to the type of fungus used and the characters and habits of the pest to be attacked. All classes of insects have their fungous enemies, - some, like the Entomophthorece, the species of Cordyceps and its Isaria condition, as well as other forms belonging to the Fungi Imperfecti, often causing serious epidemics, while others, like the Laboulbeniales, may be comparatively harmless. The idea of using fungous diseases in a practical manner to control the ravages of noxious insects is not a new one, and as early as the middle of the last century De Bary, Tulasne and others called the attention of agriculturists and orchardists to the importance of white muscardine, Isaria densa Link., as a natural check on destructive insect pests. Since the time this suggestion was originally made there have been numerous more or less successful attempts to use fungous diseases artificially, among which the following may be mentioned.

Metchnikoff (1878) cultivated Metarhizium anisoplice (Metch.) Sorokin, the so-called green muscardine, and infected Anisoptia with the spores. Krassilstschik (1884) founded a laboratory at Smelk in order to raise green muscardine in large quantities, and the spores, spread on the beet fields to infect Cleonus punctiventris, the beet weevil, started an artificial epidemic which is said to have killed from 50 to 80 per cent of these destructive beetles. Rorer (1910) has also used the spores of the same fungus, mixed with flour, in spraying sugar cane in Trinidad to control the froghopper, with some success. 
Cordyceps melolonthce Tul. has been employed against the white grub, Melolontha vulgaris, in Europe, and Giard (1893) records an attempt to use Isaria densa against the same insect in France, contrasting the results obtained with those of certain American investigators. Buisson (1892) used Botrytis tenella Sace. against the same pest.

Sporotrichum globuliferum Speg. has been used by Snow (1889), Forbes (1888), Brunner (1902) and others on the chinch bug in this country, but although various opinions have been expressed as to the success of this work, the more recent experiments of Kelly and Parks (1911) lead them to the conclusion that, although under certain conditions the fungus may be very destructive in nature, its artificial propagation is not to be recommended, an opinion in which Messrs. Billings and Glenn (1911) also concur. Brunner has also used it on the migratory locust in the Argentine Republic, and reports its use in the fight against the same pest in Sterling, Col.

Sphcerostilbe coccophila Tul., Microcera sp. and Ophionectria coccicola E. and E. have been successfully employed (Rolfs, 1907, and Fawcett, 1908) against the San José and purple scale of orange trees in Florida. During the last three or four years the use of Aschersonia aleyrodis Webber, Aschersonia flavocitrina P. Henn and EEgerita Webberi Fawcett (Fawcett, 1908, Rolfs, 1908, and Berger, 1910) has been very successful in checking the white fly in the citrus groves of Florida, a region especially well adapted for such experiments, owing to the fact that here these fungi grow naturally out of doors more or less continuously throughout the year.

Of the Entomophthorea, although the group contains some of the most destructive forms attacking economically important insects, the brown-tail fungus appears to be the only form which has been used artificially. That more of these forms have not been used is probably due to the fact that their cultivation and propagation is usually attended with the greatest difficulty.

\section{THE BROWN-TAIL FUNGUS.}

The fungus which causes the disease of the brown-tail eaterpillar is a microscopic plant known technically as Entomoplathora Auticce Reich, which has been long known in Europe 



\section{PLATE II.}

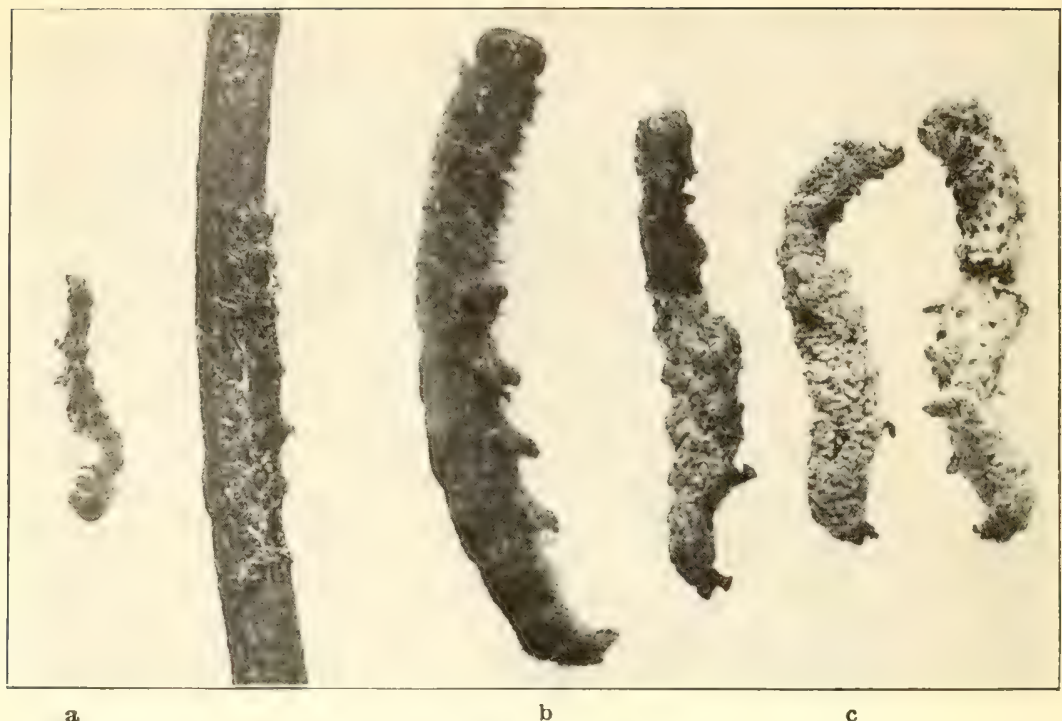

Fig. 1.

FIG. 1. - a, fypsy moth litrat from Jipun killed by an Entomophlhere disease; b, a tent caterpillar, and e, three lrown-tail larva killed hy Eutomophthora Aulicre. Thic latter were kept in a dark chamber to develop an external growth of the fungus.

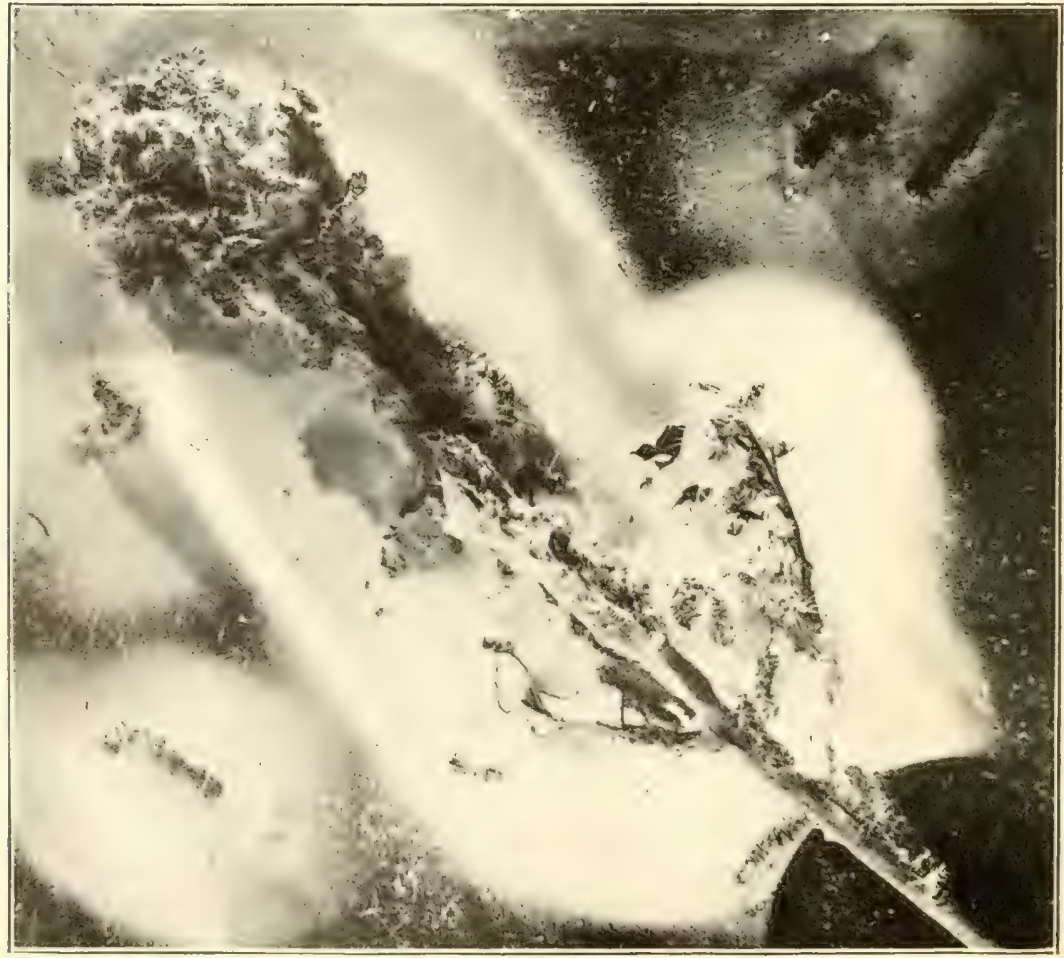

Fig. 2.

Fic. 2,-This photogratu gives some idea of the number of spores discharged. 'The branch, crowded with deat and dying caterpillars, wats laid on at sheet of glass in a still room, and the white color is entirely due to the thousands of spores which fell on the grlass during the night. 
and was first reported from this country by Dr. Thaxter in 1885. It has not only produced natural epidemics among the brown-tails since they were first introduced, but it attacks various other native species of insects, which are enumerated below. It is closely allied to Entomophthora musce Cohn, a fungus that attacks the common house fly, which may often be seen dead on a window pane or mirror, where it becomes surrounded by a white halo or whitish patch, due to the large number of

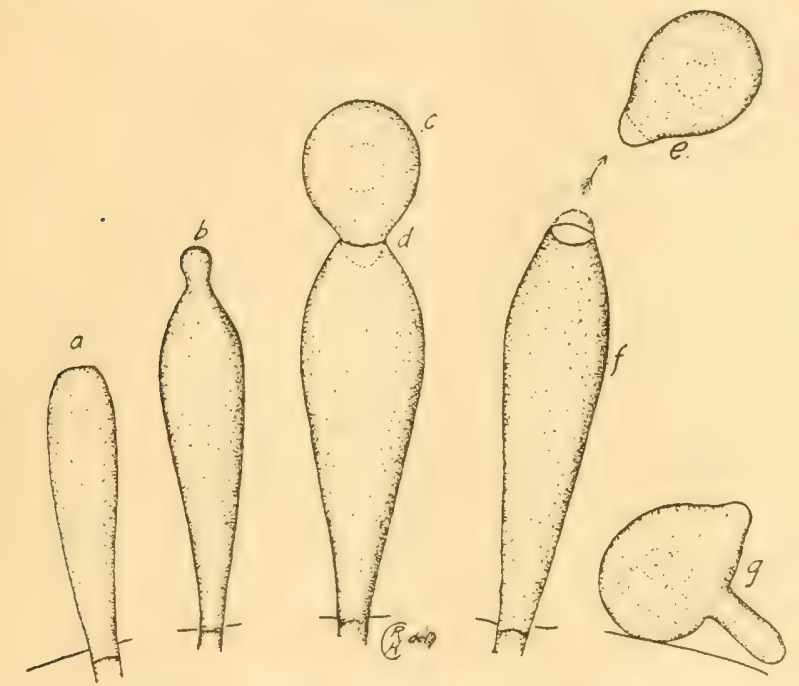

F1G. 1. - Diagram to illustrate the development and discharge of spores. At the tip of the club-shaped conidiophore $a$ a rounded bud $b$ develops into the pear-shaped spore $c$. This spore is torn away at the collar. $d$ when mature by internal pressure, and shot off from the conidiophore $f$, as indicated by the arrow at $e$. Spores produced and discharged in this manner are called conidia. At $\theta$ is shown a germinating spore with its young germ tube.

spores discharged on the glass. (Plate II., Fig. 2.) These spores, called conidia, which are the fruit of the fungus, and correspond in function to the seeds of higher plants, are ovoid to pear-shaped (Plate VII., Figs. 1-4), with a papillate base, and measure 25 to 35 by 28 to 40 thousandths of a millimeter. If a spore comes in contact with a healthy caterpillar under favorable conditions of moisture, germination takes place immediately; that is, the spore sends out a thread-like germ tube. (Fig. 1, g; Plate VII., Figs. 5-7; Plate VIII., Fig. 32.) This germ tube pierces the integument and continues to grow 
within the body of its victim for about five days after infection. Germination may also take place on any moist surface, but in such cases growth is usually very limited, and may result in the production of secondary conidia (Plate VII., Fig. 8) exactly similar to the primary conidia, which may be discharged when mature and have the same power of infecting a healthy larra. The conidia retain their power of germination for about seventy-four hours after their discharge. In nature the caterpillar is not visibly affected by the presence of the fungus in its body until the afternoon of the fifth or sixth day, when, after a brief period of nervous activity, its movements become sluggish or cease altogether. By this time the branches from the original germ tube have become brokein up into irregular chunky "hyphal bodies," which more or less completely fill the body cavity. Just before death, which usually comes toward evening, the caterpillar is almost always impelled to climb to the highest point on the leaf or twig on which it has been resting; the forelegs then lose their power, and the fore part of the body droops backward or to one side in a position so characteristic as to be easily recognized. (Plate VI.) As soon as the caterpillar is kead, or even just before death, the hyphal bodies within it send out stout germ tubes. (Plate VIII., Figs. 28-31.) The ultimate branches of these germ tubes break through the integument in pustules (Plate VIIT., Fig. 26), whirh may eventually cover the whole body with a creamy white mass of fungous growth, especially if the atmosphere is moist. At the tip of each of the club-shaped branches, called conidiophores (Fig. 1, $a, b$; Plate VII., Fig. 10), a rounded bud develops into the pear-shaped spore (Fig. 1, c,e), which is shot off with considerable force when mature by a mechanism specially developed for this purpose. Air currents may carry the spores for miles, or if they fall on the backs of other caterpillars the movement of the latter may perhaps further aid in their distribution, especially where the caterpillars are closely congregated. The number of spores which may be discharged from a single diseased larva is very large, probably reaching hundreds of thousands in the case of a full-grown caterpillar, and every spore has the power to infect another caterpillar, provided that it strikes in a favorable position for penetration 
under favorable conditions of moisture. It is interesting to note that nature has provided for the wider dissemination of these spores by impelling the dying caterpillar, as already mentioned, to climb upward, thereby placing its body in a more elevated position, from which the falling spores will be distributed over a large area. In the field the dead caterpillars are found most often on the shady under side of the limbs, near the crotches of the branches, but one may find them with little trouble on any part of the tree or on adjacent walls and fences. (Plate III.)

\section{Resting Spores.}

Besides the type of "air spores" or "conidia" just described, the fungus produces another type, formed internally, known as "resting spores," which are extremely resistant to changes of heat and cold, and which, although their germination has not been observer, undoubtedly serve to tirle the fungus over winter. They are commonly formed by the rolling together of the contents of large, irregular, fungal elements (Plate VII., Figs. 12-18) into spherical bodies, which later become enclosed in very thick walls. Spores of this type are comparatively rare, and the conditions which lead to their formation, whether they be due to internal causes, or to the effect of weather, or other external influences, are not clearly understood.

\section{Encysted Hyphal Bodies.}

In the fall the hyphal bodies may themselves also become surrounded with heavy walls, which on germination split and let out the contents in the form of stont germ tubes. (Plate VIII., Figs. 22, 23.) The latter branch freely, and give rise eventually to pustules (Plate VIII., Fig. 25), as in the case of the ordinary hyphal boilies. These encysted hyphal bodies are also instrumental in wintering over the fungus.

\section{General Conditions governing the Artificial Spread of the Fungous Disease of the Brown-tail Moth Caterpillar.}

In the case of the brown-tail caterpillar there are two periods in its life history when the Entomophthore under consideration may be effectively used, namely, in the spring and early sum- 
mer, when the larvæ have left their nests to feed on the young leares, and in the autumn for sereral weeks before the webs of the new broods are closed for the winter. During both of these periods the rapid spread of the disease is largely dependent on weather conditions, and when these conditions - warm nights and damp atmosphere - favor the growth of the fungus, artificial distribution yields truly satisfactory results, and may bring about enormous and widespread destruction; but it should be understood clearly that, even under these conditions, although the disease is evidently very important as a powerful check, it cannot be regarded as a "cure-all." In the spring, when the caterpillars are scattered all over the trees, it is comparatively easy to place the infected larvæ in among them, but in the autumn, when they are localized, feeding in the immediate vicinity of the nest, it is necessary to infect individual webs. Experience seems to point to the autumn, however, as the more advantageous time to start the artificial epidemic.

\section{Early Reports of the Disease among Brown-tails.}

Mention has been made in previous State reports of the occurrence of the disease in spring and fall epidemics. The dead larvæ on the outside of the webs (Plate I.) were first noticed during the early winter months ${ }^{1}$ of 1902 and 1903, and the frosty appearance of the nests, due to hundreds of thousands of discharged spores, led to the popular belief that the young caterpillars had been lured ont of the webs by the warm midday sum and had been frozen to death before they could return. The susceptibility of the brown-tail to this disease was first noticed by Dr. Thaxter in Maine, just after the caterpillars made their initial appearance there. He had made a series of experiments in artificial infection previous to the experiments at Kittery Point, Me., in 1907, which were reported by Professor Hitchings, and the apparent suceess of which led to the engagement of Dr. Clinton to carry on a preliminary investigation in Massachusetts.

\footnotetext{
1. See Fernald and Kirkland's Report of Brown-tail Moth Commission, 1903.
} 


\section{Preliminary Experiments of 1908.}

D1. Clinton concluded from his preliminary experiments in the spring of 1908 that the use of the disease as a check wruld be of practical value if (1) the fungus were planted in territory where the natural disease was not in evidence, and (2) if the plantings were made in the field before the natural disease could develop under ordinary weather conditions, thereby giving the introduced disease an opportunity to develop more generations, and consequently infect more larvæ than the laterstarting natural epidemic. He was hampered in his investigation by the fact that he was unable to begin operations until the season was well advanced, and the time available was so short that he was unable to make extensive experiments. His results, however, again demonstrated that the propagation of the disease in the field could be successfully accomplished.

\section{Autumn of 1908.}

Dr. Clinton being umable to continue the work after July of this year, it was taken in charge by Mr. Speare, and the first fall infection was made in the autumn of 1908, when about 500 diseased caterpillars were distributed over a limited area on low shrubbery at North Andover, Mass. As nearly as could be estimated about 35 per cent. of the young larvæ on the hillside where the planting had been made died as a result of this artificially induced epidemic.

\section{Cultivating the Fungus through the Winter of 1908-09.}

The Entomophthora from the fall infection was cultivated and kept alive through the winter months so that the spring planting could be made as early as possible, without the delay incident to spring collection and foreing of the disease. In order to accomplish this, webs were eut open and placed on a layer of filter paper over damp moss in ordinary culture dishes. A glass cover kept the atmosphere in the dishes moist and favorable to the growth of the fungus. Infected larvæ were placed in the cut nests, and in this manner the disease was transmitted to the healthy larvæ, and the fungus kept alive through successive generations. Some practice was necessary 
before the optimum moisture conditions were determined, but the chief difficulty encountered was the hostile action of other fungi, which grew very rapidly under culture-dish conditions. The worst enemy, Sporotrichum globuliferum Speg., sometimes threatened to choke out the Entomophthora entirely.

\section{Spring of 1909.}

The fungus having been propagated through the winter of 1908-09 at the Botanic Garden, about the first of March two bushels of webs were brought from cold storage and placed in two boxes, which, for the sake of convenience, will be called the "disease box" and the "rearing box." Both boxes were of the same type, their dimensions being 11 by 27 by 27 inches, and by leaving the bottoms open the contents were directly in contact with the moist earth. A two-inch rim of ordinary commercial tanglefoot served to keep the caterpillars confined. Dead and dying larvæ from the winter culture dishes were turned into the disease box, together with fresh webs containing healthy caterpillars, for the purpose of starting a general infection as soon as the latter emerged. In order to favor the spread of this infection as much as possible the atmosphere was kept moist by covering the box with a damp mat. Without attempting to force the growth of the larve in either box, they were fed just enough to keep them alive, so that the disease might be carried along through successive generations on a little larger seale than was possible with the culture dishes.

About April 1 larvæ from four bushels of cold-storage webs were placed in five rearing boxes, and the intention was to feed them to the limit of their capacity, so that they would be large enongh for infection and distribution by the 25 th of the month. Owing. howerer, to the nature of the only food which was arailable, the rearing of the caterpillars was attended with the greatest difficulty, as it was almost impossible to make them feed. Trillow twigs forced under glass were not acceptable; lettuce worked fairly well but was expensive, and the larvæ did not thrive on it, so that little or no active growth occurred until a supply of fresh food became arailahle out of doors as the season advanced. 


\section{Feeding Methods.}

The larra-were fed by two methods: (a) by placing leafy twigs in jars sunken in the earth, or (b) by throwing small quantities of stripped leaves directly on the clean earth. In the first method the leaves remained fresh for some time, but in handling the wet twigs, when changing the food or the water, the boxes often became too damp and favorable to the growth of the fungus, which, when once it gained a foothold, threatened to kill off the entire supply of caterpillars. The second method has proved to be the better for general use, because the supply of food can be easily regulated by throwing in just enough leares to keep the caterpillars eating all the time. The boxes were kept clean and sanitary by removing the dried and halfeaten leaves as soon as the larvæ crawled on fresh ones.

\section{General Methods of Infection.}

All investigators on fungous diseases of insects have experienced more or less trouble in transmitting the disease to healthy larve in the laboratory. In most cases it seems very difficult to imitate exactly the conditions under which the infection naturally occurs. What is true of other fungous diseases is in general true of the brown-tail disease, and it often happened that the fungus would get a start in the rearing boxes, where it was not wanted, and attack the larve with the virulence of an epidemic, while in the disease boxes, where the conditions rere supposed to be at an optimum for its growth, it appeared only in scattered spots. The three methods used for general infection may be outlined as follows:-

(a) Infection by the "Crate Method." - A crate $51 / 2$ by 30 by 30 inches, with a mosquito neiting bottom, was fitted tightly orer a second crate of similar dimensions, in which the healthy larvæ mere placed. Caterpillars dying from the disease or those already dead and ready to discharge spores were placed at short intervals on the netting bottom of the upper box, so that the spores from their bodies mould drop through the meshes of the netting upon the healthy larvæ below.

(b) Infection by the "Spray Method." - Dead caterpil- 
lars were placed in an atomizer bottle so that all of the spores discharged would be canght on the glass. After spore discharge had ceased, and the bodies of the caterpillars had been removed, the bottle was filled with water, the spores were dislodged from the sides and bottom with a soft camel's-hair brush, and the "spore water" was then sprayed over healthy caterpillars in an ordinary rearing box.

(c) Infection by the "Natural Method." - Infected larvæ were mixed with healthy ones all over the twigs and leaves in a rearing box. Following their natural instinct to $\operatorname{climb}$, the diseased caterpillar's placed their bodies in such elevated positions as the tips of the twigs and sides of the box just under the rim of tanglefoot, so that the spore discharge was directed against the borlies of the healthy caterpillars and in every direction over the leaves.

By taking lots of 100 at random from these boxes, after they had been exposed to the spray or spore discharge for three or four dars, placing them in small trays and counting the number which died from the disease within nine days, it was found that the maximum infection was hardly more than 40 per cent. ${ }^{1}$ The last method appeared to be the most favorable, and was adopted for the infection of all of the material sent into the field.

\section{General Methods of Distribution.}

After trying several schemes for distributing the infected larvæ it was concluded that the method first used by Dr. Clinton could not be bettered for general use, because of its simplicity and comparatively low cost. The method in brief is as follows: From 20 to 30 caterpillars which had been exposed to the spore discharge were placed in a quarter-pound paper bag. the neck of which was wound tightly with a 10-inch strand of No. 26 iron wire. The bag was then hung in the tree as near the web as possible, or near the masses of feeding caterpillars, and its side ripped open to allow the infected larvæ to escape. In addition to this bag method, wherever it was pnssill. the sick caterpillars were placed directly in the feeding masses, thus practically insuring an infection.

1. This maximum was increased by a combination of methods to 75 per cent. in 1911 . 



\section{PLATE III.}

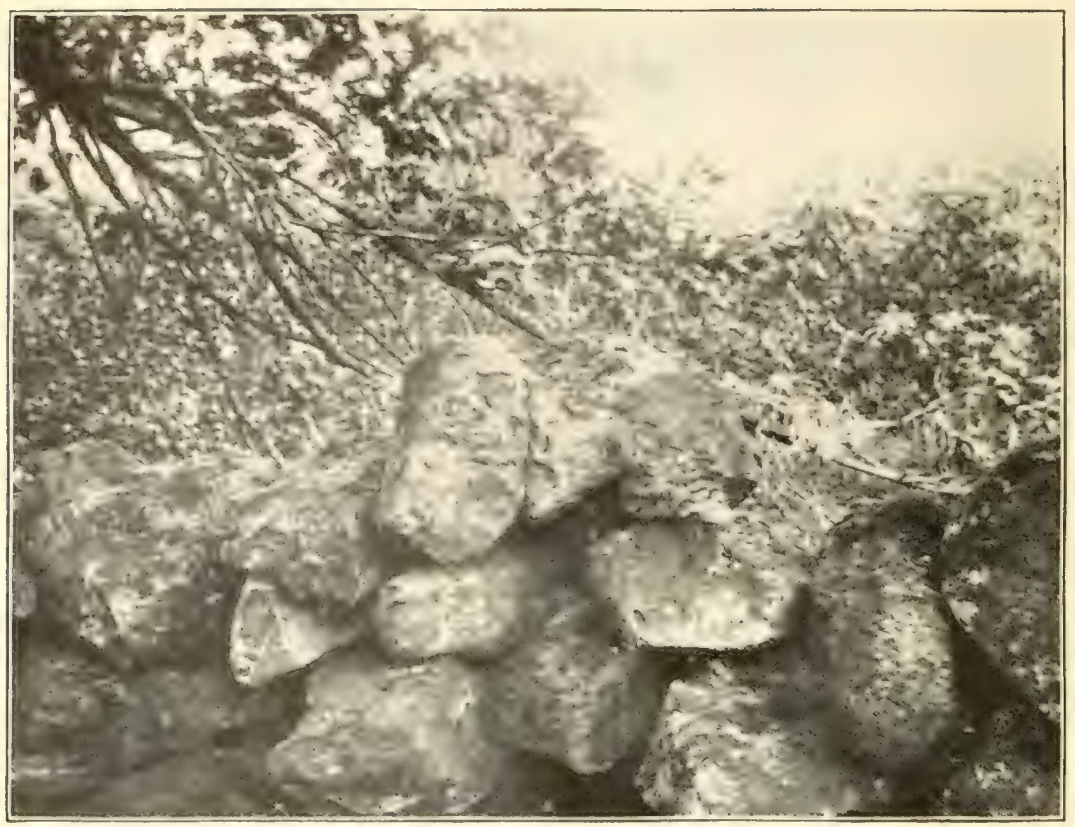

Fig. 1.

Fig. 1.- Showing dead larve on the top of an old stone wall at South Billerica.

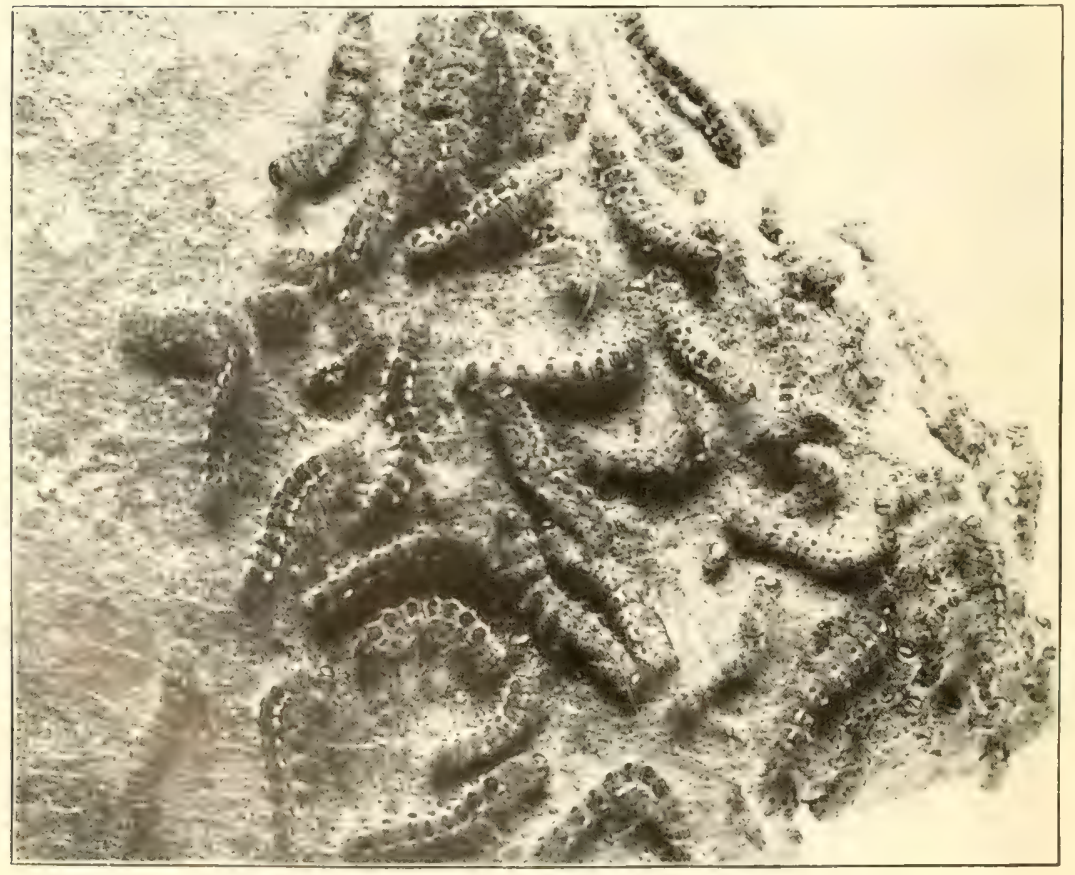

Fig. 2.

FIG. 2. - I view of a single stone of the above wall. Alt of the larra shown are dead from the Entomophthora discase. 
The plantings ${ }^{1}$ of the spring of 1909 were made by the two methods just described. In nearly every case the larve crawled out of the bag in a few minutes, but in the first two plantings made in late April, the cold rendered their. movements so sluggish that they died before they could escape. The last three plantings were made so late in the season that they could not have been very effective. The season's work proved that artificial spread before May 1 is useless, because the irregular cold weather of late April inhibits the growth of the fungus, and that it is extremely difficult to estimate the effectiveness of plantings made after May 25 on account of the prevalence in the field at this season of spontaneous epidemics. In the territories of Rowley and West Newbury, where the disease workel very successtully, the final mortalities among the prepupæ and pupæ ranged from 80 to 90 per cent., and in localized plots of intense infection it was impossible to find a single live individual.

On TLay 14 the number of caterpillars dead from the disease on the territory at North Andover, planted the previous fall, was estimated at 50 per cent., and on May 28 at 95 per cent. The epidemic had apparently spread about equally well in all directions. Inspection of the estate of Mrr. William Brewster at Concord, where a natural infection had occurred in the fall, showed that the caterpillars were practically annihilated by the 24th of May. It seemed probable that the epidemic in the North Andover territory had been started by the diseased caterpillars planted there in the fall of 1908 , since there was no indication of the fungus in that locality previous to their introduction, and in both cases the early appearance of the disease in the spring, and the intense destruction wrought by it, seemed to point to the conchusion that the fungus had wintered over in the nests, and begun its attack as soon as the young larvæ emerged.

\section{Autumn of 1909 .}

In the autumn of 1909, the supply of webs in cold storage being insufficient, only three plantings were made, two of which were effective in killing off 20 to 30 per cent. of the larre, thus

1 See page 26 for list of localities planted. 
confirming the results of the preceding fall; the other was spoiled for observation because the infected webs were cut from the trees and burned by the owner of the property.

\section{Spring of 1910.}

The fungus was carried over the winter of 1909-10 in culture dishes by the method already outlined, and a general infection started in the disease boxes in the usual manner. A disastrous epidemic of Sporotrichum globuliferum Speg., which killed off a large number of the larve and threatened to choke out the Entomophthore altogether, was controlled only with the greatest difficulty. In spite of this hindrance, however, a sufficient quantity of infected material was ready for planting on the 1st of May. The diseased caterpillars were distributed over a solid block of territory about twelve square miles in extent, running along the railroad track from Ipswich to within one mile of the New Hampshire line, and also in six scattered plantings on private estates. Weather conditions were favorable, and regular inspection at intervals during late May and early June rerealed a mortality estimated at about 35 per cent., with the disease universally distributed through the planted areas. The virulence of the epidemic gradually increased until the larvæ began to spin up, about the middle of June, when the per cent. of those visibly affected rose so high that only 80 out of 1,000 pupæ and prepupæ collected from all over the planted territory matured moths.

It might be stated here that the word per cent. as used abore shonld not be taken in its literal sense, as it is impossible to arrive at an absolutely correct determination of the work of the fungus at any given moment. The reasons are obvious. Only those caterpillars risibly affected with the disease at the time of inspection can be used in the calculation, which means that all larve which have died and dropped from the trees, as well as those infected but not yet dead, must be inevitably overlooked. Moreover, at the time of inspection the disease may be at a very low ebb, due to adverse weather conditions or some other cause, and the inspector will get the impression that the fungus is not working at all. Territories in which the disense ap- 
peared to be working to perfection in May often exhibit only scattering evidence of the destruction wrought when inspected in June, and in other territories the June death rate may be the highest of the season. Since the conditions in the field are so variable, careful inspections and estimates must be made at intervals throughout the entire season in order to arrive at even an approximate estimation of the total work that the fungus has done.

\section{Autumn of 1910.}

Seventy bushels of webs were brought from cold-storage on the 25th of July to furnish the larve for the fall infection of this year. The caterpillars were placed in long rearing boxes out of doors under favorable conditions for their growth, but an attack of the disease, which started from one box in which there must have been a few infected webs, and spread rapidly to all of the others, killed off 90 to 95 per cent. before the 20th of August. The few that survived were evenly distributed in five disease boxes, and with them were mixed healthy larvæ from the webs in the field. Although this meager supply of diseased material was unsatisfactory, about forty plantings were made, with the co-operation of the State agents and superintendents, on low shrubbery in eastern Massachusetts. A new method of sending the caterpillars to the field, in mailing cases. was tried in connection with these plantings, and proved to be satisfactory, except in those instances where the cases were delayed in the mails until the larvæ were dead when they arrived at their destination. In making the plantings all the nests that could be conveniently reached were ripped open, so that a few of the infected caterpillars could be inserted directly among the healthy occupants. The bag method was also used successfully. Where the contour of the comtry permitted, the plantings were made at 50-foot intervals, and the whole planted territory divided into plots of convenient size for careful observation. A count of all of the nests in a selected plot was recorded at the time of planting, so that the spread of the disease might be checked up at each inspection. The reports of the inspectors showed that the disease became evident after ten days in every plot, and that the number of dead larve on 
the outside of the nests increased very rapidly, first in the immediate vicinity of the infected web, and then in scattered spots all over the territory. The following typical report from two inspections of a planting made August 13 at Clinton gires some idea of the rapid death rate. One bag, containing 15 to 20 diseased caterpillars, was hung in the middle of each plot, and the plots so chosen that the bags were about 50 feet apart.

\begin{tabular}{|c|c|c|c|c|c|c|c|c|}
\hline \multicolumn{4}{|c|}{ Plots. } & \multirow{2}{*}{$\begin{array}{l}\text { Total Number } \\
\text { of } \\
\text { Webs in Plot. } \\
12\end{array}$} & \multirow{2}{*}{$\begin{array}{c}\text { Webs } \\
\text { Infected } \\
\text { September } 10 . \\
4\end{array}$} & \multirow{2}{*}{$\begin{array}{c}\begin{array}{c}\text { Dead Larva } \\
\text { September } 10 .\end{array} \\
67\end{array}$} & \multirow{2}{*}{$\begin{array}{c}\begin{array}{c}\text { Webs } \\
\text { Infected } \\
\text { September } 15 .\end{array} \\
10\end{array}$} & \multirow{2}{*}{$\frac{\begin{array}{c}\text { Deau Larva } \\
\text { September } 15 .\end{array}}{231}$} \\
\hline I., & - & - & - & & & & & \\
\hline II., & - & - & - & 10 & 3 & 46 & 9 & 340 \\
\hline III., & - & & - & 23 & 6 & 149 & 15 & 410 \\
\hline IV., & $\therefore$ & - & . & 20 & 6 & 78 & 13 & 177 \\
\hline
\end{tabular}

The area of each plot was between 400 to 500 square feet. The same results were reported from the other plantings, which were practically all successful, resulting in the infection of 35 . to 50 per cent. of the webs in the planted areas.

\section{Spring of $1911 .^{1}$}

Following the same general methods in rearing, infecting and distributing the caterpillars used in previous experiments, the work of the spring of 1911 was continued on a still larger scale. The only change in the rearing and disease boxes was the use of heavy wire screening with a quarter-inch mesh on the bottoms, to retain a thin layer of earth and prevent the escape of the larvæ whenever the boxes had to be moved. The late spring, and consequent late opening of the foliage, made the work of early rearing very difficult, and it was necessary to draw on a supply of raspberry leares, grown in the greenhouse and intended for use in raising gypsy larve, until the willow and cherry trees came out. Beside the extensive plantings made by two men employed especially for the purpose during the month of May, a general distribution of infected caterpillars was made possible with the help of the State agents. Ship- 
PLATE IV.

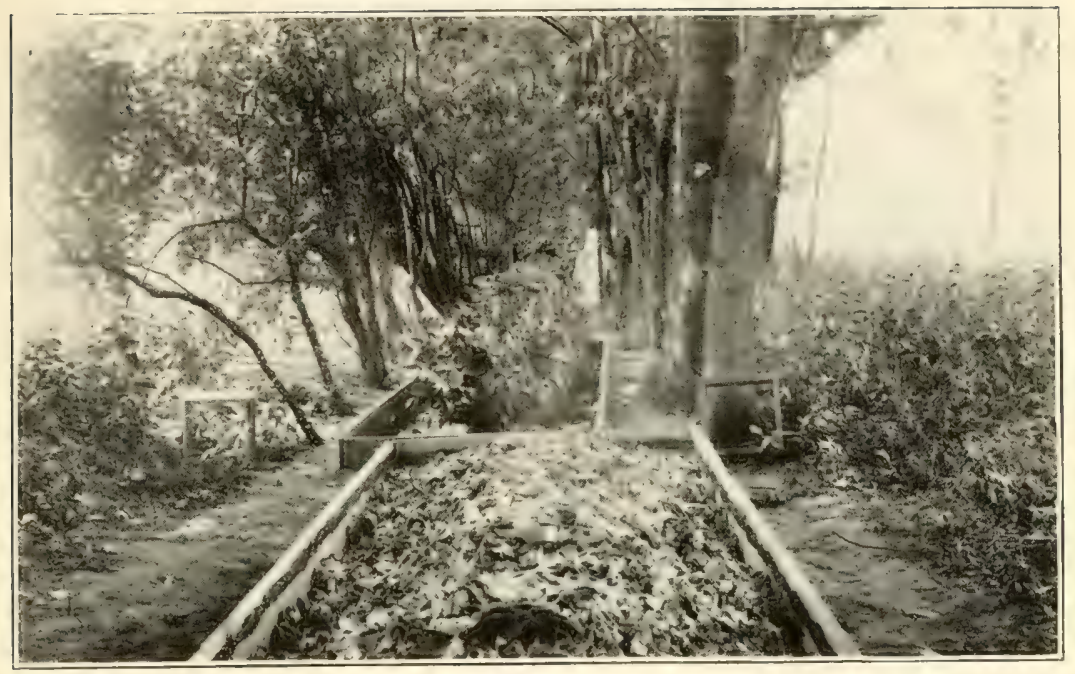

Fig. 1.

Fig, 1.-Long rearing hoxes under the trees at the Botanic Garden, used to foree the larva for the infeetion experiments of the fall of 1910.

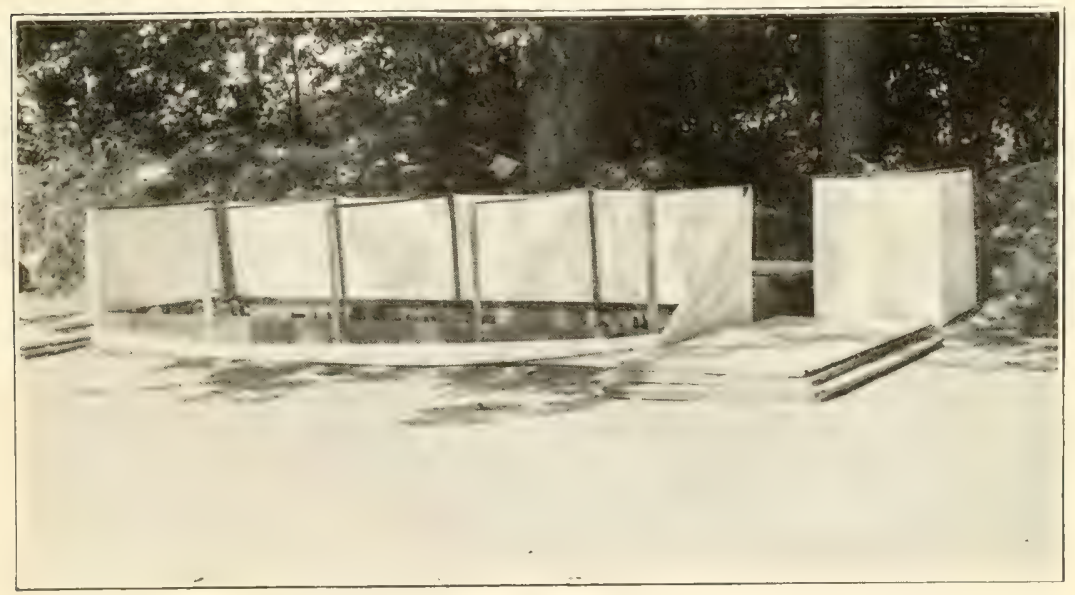

Fig. 2.

FiG. 2,- Rearing boxes protected by cotton drilling to prevent the spread of an epi. demic of the disease in the fall of 1910. It was thought that the cotton eloth would stop spores from being blown in from the infected boxes. 

ments were made also to interested persons all over the State for private experiment, as long as the material lasted.

The extreme dryness of the month of May hindered the growth of the fungus to a very large extent, so that the final results were not as good as those of the preceding spring, but toward the end of the season there was a general infection all over the planted territory. In and around Ayer the number of caterpillars visibly affected with the disease on the 27 th of June was estimated at 60 to 70 per cent., and the trees in which the fungus had been planted were not nearly so badly stripped as those in which the caterpillars had been unmolested. In contrast to this condition a badly infested scrub growth of oak and cherry in Roberts, where no fungus had been planted, was completely defoliated, and the natural disease, though evident on one or two bushes, was not present in epidemic form.

Early inspection of the plantings made in the autumn of 1910 showed that the infection was general, but was not spreading far from the planted areas, except in one or two instances. In spite of this fact the defoliation in these areas was noticeably less than in areas where no fungus had been distributed. As in the spring of 1910 , the death rate after the 15th of June increased very rapidly, and in Georgetown, where an excellent infection was started the previous September, the caterpillars in the planted territories were almost completely annihilated. The territory between Ipswich and Rowley, which is damp nearly all the time, on account of the proximity of the ocean and salt marshes, was found to be practically cleared of browntails by the disease.

\section{Autumn of 1911.}

In preparation for the fall infection the larva were brought from cold storage on the 15th of August, three weeks later than in previous seasons, and fed wholly on cherry. Fortunately, the disastrons results which attended our efforts to force the caterpillars in July and August, 1910, were not repeated, so that ten bushels of webs furnished an abundant supply of larvæ about one-half inch long by the 1st of September. It was found advisable to cover the bottoms of the rearing boxes 
with a thin layer of coarse gravel, which was a great aid in keeping the boxes clean. Two disease boxes had been run all summer, and from them infection was started in seven others. The latter were all arranged as shown in Fig. 2, and by a combination of the "natural method" and the "spray method" a comparatively high per cent. of infection was obtained. The - following table shows the results obtained in fire test experiments. In each case the caterpillars were picked at random from the disease boxes and packed in mailing cases for several hour's, as if they were to be shipped to agents in the field, to imitate the normal conditions of distribution, before being placed in the observation trays.

\begin{tabular}{|c|c|c|c|c|c|c|c|c|c|}
\hline \multicolumn{7}{|c|}{ Trays. } & \multirow{2}{*}{$\begin{array}{c}\begin{array}{c}\text { Number of } \\
\text { Larva placed in } \\
\text { Tray. }\end{array} \\
180\end{array}$} & \multirow{2}{*}{$\begin{array}{c}\begin{array}{c}\text { Number of } \\
\text { Larve dying within } \\
\text { Nine Days. }\end{array} \\
97\end{array}$} & \multirow{2}{*}{$\begin{array}{c}\begin{array}{c}\text { Approximate } \\
\text { Per Cent. }\end{array} \\
53\end{array}$} \\
\hline I., . & . & . & . & . & . & . & & & \\
\hline II., . & . & - & . & . & - & . & 253 & 204 & 80 \\
\hline III., . & . & - & . & - & . & . & 219 & 183 & 83 \\
\hline IV., . & . & - & . & - & - & . & 144 & 109 & 75 \\
\hline V., . & . & . & . & . & . & . & 129 & 97 & 75 \\
\hline
\end{tabular}

Planting was commenced on the 1st of September and ended on the 12th, during which time approximately 100,000 caterpillars were distributed, a great increase over the number distributed in the fall of 1910 . The caterpillars, packed in mailing cases as before, were delivered by automobile, a method which assured their reaching the agents in good condition, because by its use unnecessary delay in transit was avoided. IVith one or two exceptions all of the infected caterpillars were planted directly in the nests.

About the middle of October an inspection of all the nests on plotted areas in plantings in Walthan, Stow, Marlborough and Hudson showed a general infection, about half of the mests examined being diseased. ${ }^{1}$ In all of this autumn's work only three cases of naturally infected webs were observed, a fact which led to the conclusion that the epidemic in these arens 
was due to the infection started by the introduced caterpillars. There is every indication that, with favorable weather conditions, the work of the fungus will be evidenced in the spring of 1912 by a more or less complete annihilation of the brown-tails in and around the territories where the plantings were made this last autumn.

In summing up the results of the investigations covering the four seasons 1908-11, it may be said that it has been found possible to propagate the disease in the laboratory, and to infect caterpillars in the field successfully, both in the spring and in the fall. Under farorable weather conditions the artificially induced spring epidemics have resulted in many cases in the practically complete destruction of the larvæ in the planted areas. In the fall epidemics the number of nests infected at the eurl of the season has ranged from 30 to 50 per cent., and these nesfs have apparently formed the starting point of early spring infections. The fall plantings have, therefore, a twofold efficiency, in that they not only result in the destruction of one-third to one-half of the caterpillars in the autumn, while they are small and comparatirely harmless, but also, by establishing the disease in the nests, enable an epidemic to get started much earlier in the spring than any natural infection could develop under ordinary weather conditions. The last three or four years have not been particularly favorable for natural epidemics or for furthering the spread of the introduced disease, and it seems reasonable to suppose that the fungus would have been far more effective if the weather, especially during the spring months, had been warmer, with a larger rainfall. It has, of course, been impossible to plant all of the infested territory with discased caterpillars, and in many cases areas cleared of brown-tails by the fungus in the spring have heen invaded by moths from uninfected localities, with the result that they were infested as badly as ever in August. This condition of affairs is unavoidable, since we are dealing with a moth that may fly, or be blown, for some distance, and it is therefore impossible to guarantee that the fungus will clear any territory of moths so that it will remain free for any length of time. The presence of the disease does not ren- 
der a territory immune to future immigrations, but it certainly will reduce the amount of damage that the invading moths may do. The determination of the distance to which the disease may spread is extremely difficult. Undoubtedly the spores are often blown for miles, and in such cases the epidemic might jump from one territory to another widely separated from it, but there would be no means of telling just where the spore or spores which started the second epidemic came from. As can be seen from the table on page 18, one bag of 20 to 30 diseased caterpillars is sufficient to infect an area of approximately 625 square feet; any further spread of the disease would be variable, and dependent upon weather conditions.

\section{Webs in Cold Storage.}

Before giving general directions for private experiment it seems advisable to mention the advantages of having a supply of webs in a cold-storage warehouse, or packed in a dry box in an icehouse where the temperature does not go over 35 degrees, to furnish the proper amount of material at short notice for spring or fall work. It is difficult to collect larvæ just when they are needed in the spring, for the caterpillars have usually started to feed, and it is impossible to collect them in the summer in time for the fall work, for they do not emerge from their eggs mint the middle of August. Care should be taken that such webs as are selected for this cold-storage supply are not infected with the disease at the time of collection, for if they are it will become epidemic when the nests are brought out into the warmer air, and completely destroy the larvæ in the rearing boxes.

\section{Directions for Private Experiment.}

With such a supply of webs to draw from, persons wishing to make prirate experiments might proceed something as follows:-

Two boxes should be constructed after the manner shown in Fig. 2, and set in two frames (Plate T., Fig. 2) some distance apart one for rearing the caterpillars and one for forcing the disease. The bottoms of both boxes should be covered with a 
PLATE $\nabla$.

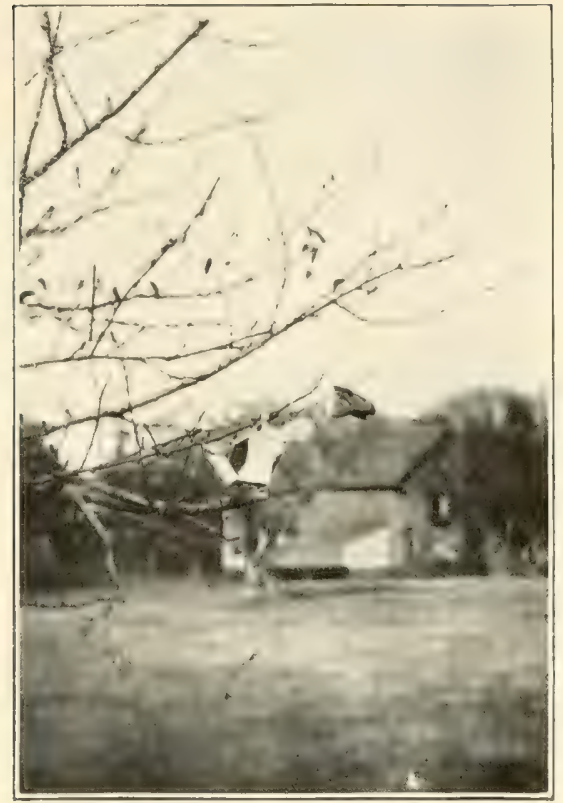

Fig. 1.

Fit. 1. - Showing the proper method of langing the bag containing the infected caterpillars close to the nest.

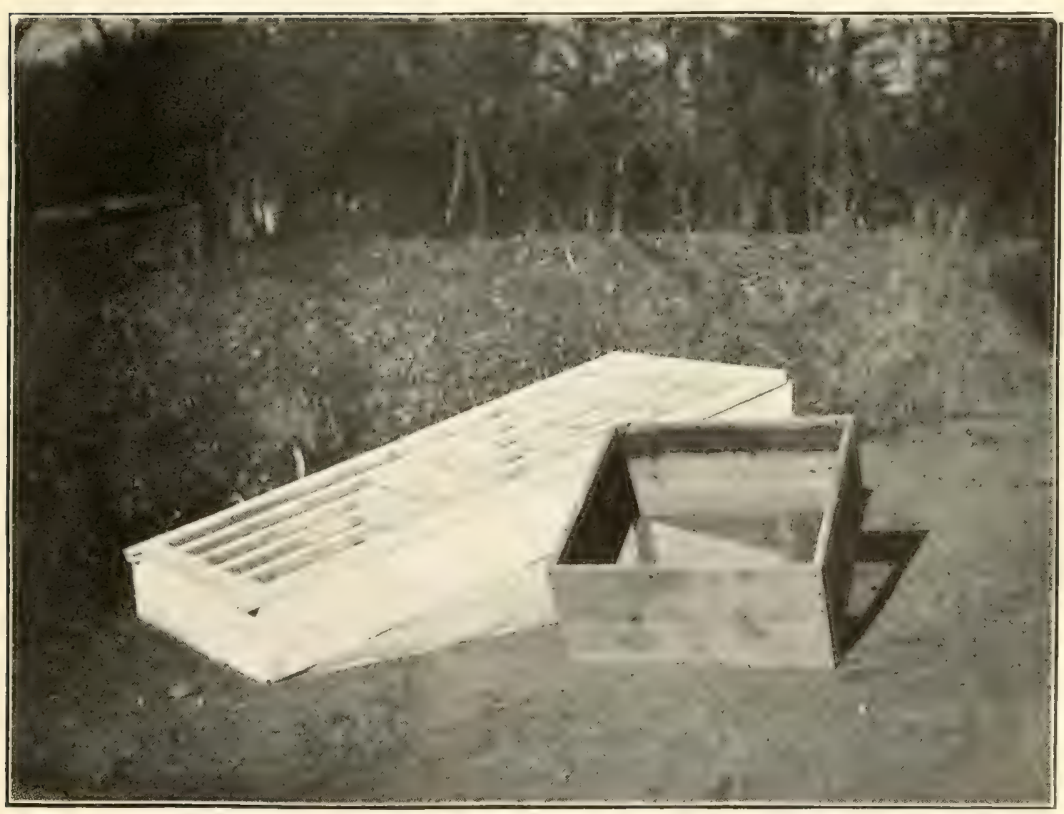

Fig. 2.

Fig. 2. - A clieap but eflicient frame and disease box for private experiment. 

thin layer of gravel. About April 1, 200 stored or freshly cut webs should be placed in each box, and in addition to this number the box chosen for the disease box should also receive two or three dozen infected webs from some locality where the disease is known to be present.

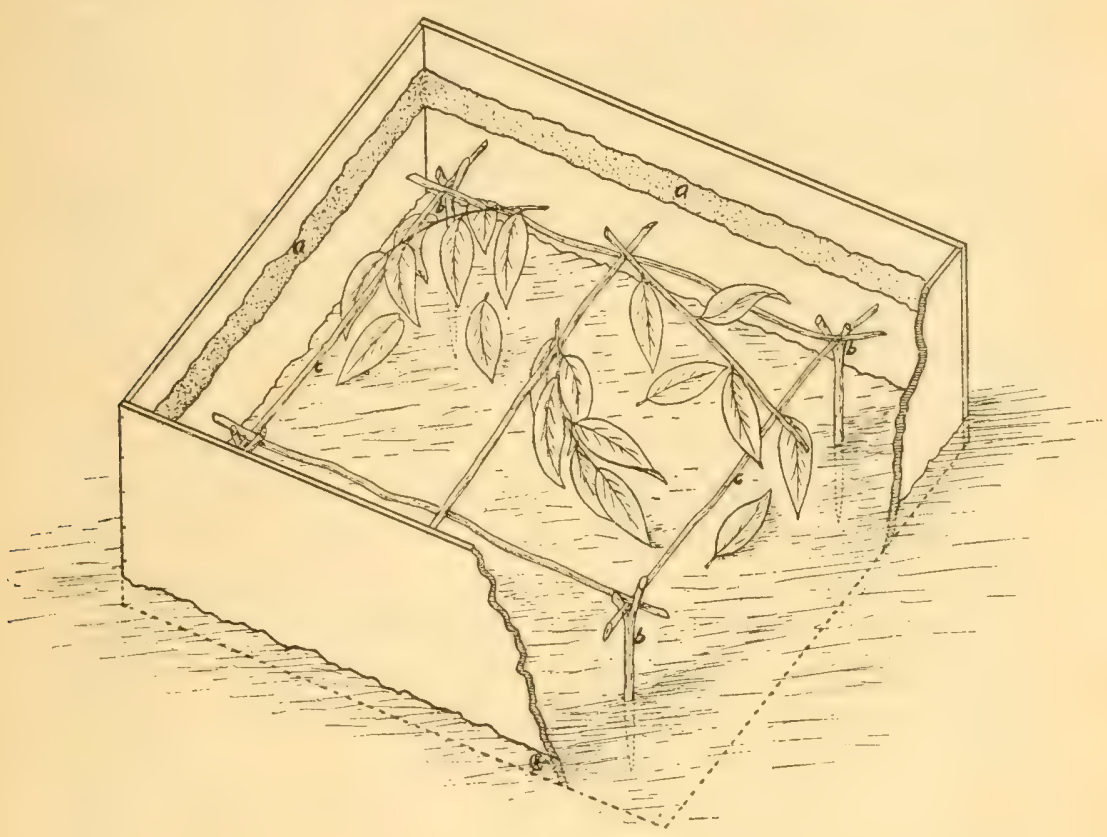

Fig. 2. - Diagrammatic view of the interior of a rearing or disease box. Forked sticks $b b b$ driven into the ground support crosspieces $c c$, on which leafy twigs may be hung. Other leaves should be scattered on the ground beneath the crosspieces. Infected caterpillars will usually crawl up the forked sticks and along these crosspieces, so that the spores from their bodies will fall on the healthy larvæ feeding below. A two-inch rim of tanglefoot in the position indicated by a will keep the caterpillars confined.

In the matter of food, sanitation, heat and shade experience is the only reliable guide, but in general, young buds, stripped from oak or cherry trees, make the best material for carly feeding; the boxes, especially the rearing box, should be kept as clean as possible, and the shade should be arranged so that the temperature does not go much over 80 degrees. The disease box should be kept dark and moist most of the time by corering with a damp mat, but here again the rule is not withont excen- 
tion. The rim of tanglefoot, indicated in Fig. 2, should be frequently combed.

After about ten days, by which time the disease should have made its appearance, the disease box should receive constant attention. Each night and morning the dead and dying caterpillars should be evenly distributed among the other larve in the box, in order to make the infection as general as possible. The "spray method" outlined on page 13 should be used in conjunction with this "natural method." Furthermore, it is particularly important, in the attempt to hasten the general infection, that the number of larve in the disease box should be kept nearly constant, by transferring healthy caterpillars from the rearing box to replace those killed by the disease. Broad-pointed forceps should be used in handling the caterpillars.

Planting should be commenced about the first of May, and can be continued to advantage until the first of June. Twenty to 30 of the caterpillars which have been exposed to the spore discharge in the disease box should be placed in a quarterpound paper bag, the neck of which should then be tightly wired with a convenient strand of No. 26 iron wire, or other suitable material. The bag, when it has been hung as near as possible to the masses of feeding larre or to the nests (Plate V., Fig. 1), should be ripped open to allow the escape of the infected eaterpillars.

For successful autumn planting a supply of cold-storage webs is absolutels necessary, because the fungus must be kept alive through successive generations during the summer months in the disease box, and to do this one must have a few webs on hand all the time. Moreover, as stated before, the larvæ in the field are not large enough for convenient handling in the fall experiments. The rules given for spring rearing and infection hold in general for the autumn work, except that it is not necessarv to keep the boxes under glass. Autumn planting should be direct, that is, infected caterpillars should be placed directly into nests conveniently reached, a method which insures an infection and which is simpler than the bag method. Pliable branches may be pulled down with a honked pole. Where there are a number of nests on a small bush the central nest may be 
directly inoculated and the surrounding nests tied up to it with a piece of heavy cord, which may be cut at the first inspection, after the infection has spread. Another method, devised by Dr. Thaxter, is as follows: cut, infect and bind together half a dozen or more nests. To one end of a string of convenient length attach a small stone, throw the stone over the infested tree and pull the bunch of webs attached to the other end of the string up into the topmost branches, where the nests are usually crowded and the infection will do most good. All of these suggestions can be varied to suit conditions of moisture, contour and shrubbery on the territory which is to be planted. Where it is convenient the nests which have been cut from fruit trees may be piled in an open field or in swampy pasture land and the infection started in the pile. Such a method will result in the practically complete destruction of the caterpillars, will allow the escape of insect parasites which would be killed by burning, and will establish the starting point for an epidemic which should spread to the surrounding bushes and trees. It has been found advantageous in some cases to burlap the trees in which the fungus has been planted, especially in the spring, as the caterpillars, in crowding together under the burlap, easily transmit the disease to one another.

\section{Conclusions.}

The artificial propagation and use of the brown-tail fungus has been clearly shown to be an effective means of destroying the caterpillars of this insect in great numbers and over considerable areas.

Although the success of this artificial use is variable, owing to the fact that the degree of warmth and moisture most favorable for the growth of the fungus, and dependent on weather conditions, cannot be controlled, the introduced disease can in general be depended on to kill from 60 to 100 per cent. of the caterpillars in the planted areas.

Plantings of the infected caterpillars should be made preferably in localities where the natural disease is not known to be present, in the spring from May 1 to June 1 , and in the autumn from August 25 to September 10.

The fungus usually lives orer winter from the autumn infec- 
tion, and does effective work, as is evidenced by the early appearance of the disease and the reduction of the spring defoliation in localities where it was introrluced the preceding fall, and for this reason fall infection is doubly effective.

Artificial distribution is most easily accomplished in spront woodlands and pastures where the ordinary methods of control. such as spraying and cutting, are not employed, and where the nests are more readily accessible.

\section{List of Localities where the Fungus has been planted.}

Spring, 1908. - Concord, Gerrish Island, Me., South Billeriea, State Line, Waltham.

Fall, 1908. - North Andover.

Spring, 1909. - Ballardvale, Chelmsford, Concord, Lowell Junction,

Newburyport, North Andover, North Wilmington, Rowley, Salisbury, West Newbury, Woburn.

Fall, 1909. - Mishawum, North Wilmington, Newbury.

Spring, 1910. - Territory along railroad track from Ipswich to New

Hampshire line. Scattered plantings on six private estates.

Fall, 1910. - Amesbury, Andover, Billerica, Bolton, Boston, Boxford,

Clinton, Cohasset, Dracut, Georgetown, Groveland, Fitchburg,

Framinghan, Harvard, Leominster, Lunenburg, Medfield, Methuen,

Newbury, North Andover, Reading, Rowley, Scituate, Shirley,

Tewksbury, West Newbury, Worcester.

Spring, 1911. - Intensive planting in and around Ayer. Dunstable,

Groton, Leominster, Lumenburg, Pepperell, Shirley, Stony Brook.

Westford, Whalom.

Fall, 1911. - Amesbury, Arlington, Ashland, Bedford, Belmont, Berlin,

Boxford, Burlington, Carlisle, Concord, Danvers, Dedham, Dover, Fayville Dam, Framingham, Georgetown, Groveland, Hamilton,

Hopkinton, Hudson, Ipswich, Lakeside, Lexington, Lincoln, Lynn, Marlborough, Malden, Melrose, Merrimae, Needham, Northborough, North Realing, Newbury, Roberts, Salisbury, Saugus, South Acton, Southborough, Stoneham, Swampscott, Wakefield, Waltham, Wellesley, Weston, West Acton, West Newbury, Wilmington, Winchester, Woburn.

This list indicates the localities where the fungus has been planted, but not the number of plantings. In many instances sereral plantings were made in the same town. 
List of Hosts of Entomophthora Aulice Reich. reported in the United States. Hosts of Empusa grylli Fres. are excluded.

Agrotis sp., cutworm, .

- Thaxter. ${ }^{1}$

Catocala sp., . . . . . . . . Clinton.

Estigmene acraea, salt-marsh caterpillar, . . . Clinton.

Euproctis chrysorrhoea, brown-tail moth caterpillar, Kirkland, Stone and others. ${ }^{2}$

Hyphantria textor, fall webworm, . . . . Thaxter. ${ }^{3}$

Lithophane (Xylina), cutworm, . . . . . Thaxter.

Malacosoma americana, tent caterpillar, . . . Clinton.

Mamestra sp., cutworm, . . . . . . Thaxter. ${ }^{1}$

Orgyia nova, rusty tussock moth, . . . . Thaster. ${ }^{3}$

Phlegethontius carolina, tomato worm, . . . Thaxter. ${ }^{1}$

Phlegethontius celeus, tomato worm, . . . . Thaxter.

Pyrrharctia isabella, Isabella moth, . . . . Thaxter. ${ }^{3}$

Spilosoma virginica, yellow bear, . . . . $\left\{\begin{array}{l}\text { Thaxter. }^{3} \\ \text { Webster. }\end{array}\right.$

Euchetes Egle, . - . . . . . Thaxter, herb.

Smerinthus modestus, . . . . . . Thaxter, herb.

Amphipyra pyramidoides, . . . . . Thaxter, herb.

Larva of diurnal lepidoptera, probably Vanessa, . Thaxter, herb.

Larva of diurnal lepidoptera, sp., . . . . . Thaxter, herb.

1 Ann. Rept. Connecticut Agri. Exp. Sta., 1890; 95, 1891.

2 Ann. Rept. Mass. Supt. Suppression of Gypsy and Brown-tail Moths, 1, 130, 1906.

3 Mem. Boston Soc. Nat. History, IV.; 159-162, 1888.

4 Journal Cincinnati Soc. Nat. History, XVI,; 175, 1894.

\section{EXPERIMENTS WITH THE GYPSY FUNGUS.}

In the spring of 1908 , while Dr. Clinton was carrying on preliminary experiments with the brown-tail fungus, he received from the Melrose laboratory specimens of Japanese gypsy larvæ, shipped from Japan with other material, which had been killed by the attack of an Entomophthora, but owing to the fact that the caterpillars had been dead for some weeks, all attempts to make this fungus develop its spores were unsuccessful. As it was thought that this species of Entomophthora might be as effective in destroying the gypsy larvæ as Entomophthora Aulicce was in destroying the brown-tail, Dr. Clinton, through the generosity of a friend of Harvard University, was sent to Japan to obtain the living fungus, and after great difficulties strceeded in bringing a few infected Japanese cater- 
pillars to Cambridge. Of the few larvæ which survived the long trip and serere heat only two developed the disease. These two were put immediately into a moist culture dish, so arranged that the spores would be discharged on healthy caterpillars. Only one of the latter developed typical conidia, but the growth was so feeble that probably very few spores were discharged. The pustules of conidiophores and attached spores were picked off and transferred directly to healthy caterpillars. and the dead bodies of the few larve which had dereloped resting spores were carefully saved. The caterpillars directly inoculated showed signs of the disease externally on the eighth day after infection, but in no case was the appearance typical. From this generation of the fungus 30 caterpillars were inoculated directly as above, and br successive transfers the number which dereloped the conidial form of the disease was increased steadily, though slowly. Resting spores were gencrally formed with the conidia. By the time the disease was running well in the infection boxes the larva in the field had practically all become prepupæ or pupæ, and since the attempt to raise caterpillar's from cold-storage eggs was unsuccessful, the disease, from lack of hosts on which it could be propagated, died out late in August.

Healthy gypsy larra were put into the infection box of the previous spring on May 15, 1910, and the disease, which developed spontaneously on the $2 \mathrm{~d}$ of June, was kept running until the last of August. Reinfection was undoubtedly accomplished through the germination of some of the thousands of resting spores, formed during the previous season, which were lying on the bottom of the box. From June 15 to July 2 six plantings were marle, following the same methords used successfully with the brown-tail fungus, in Billerica. Brookline, Lymn, Saugus and North Wilmington, but regular and careful inspection of these plantings revealed neither the conidial nor the more common resting-spore stage of the fungus.

In the spring of 1911 the same plantings were inspected carefully to see whether the disease had possibly started as a result of the infection made in 1910 , but no indication of its presence was discovered. The disease boxes at the garden had not been disturbed during the winter. so they contained all the 
PLATE VI.

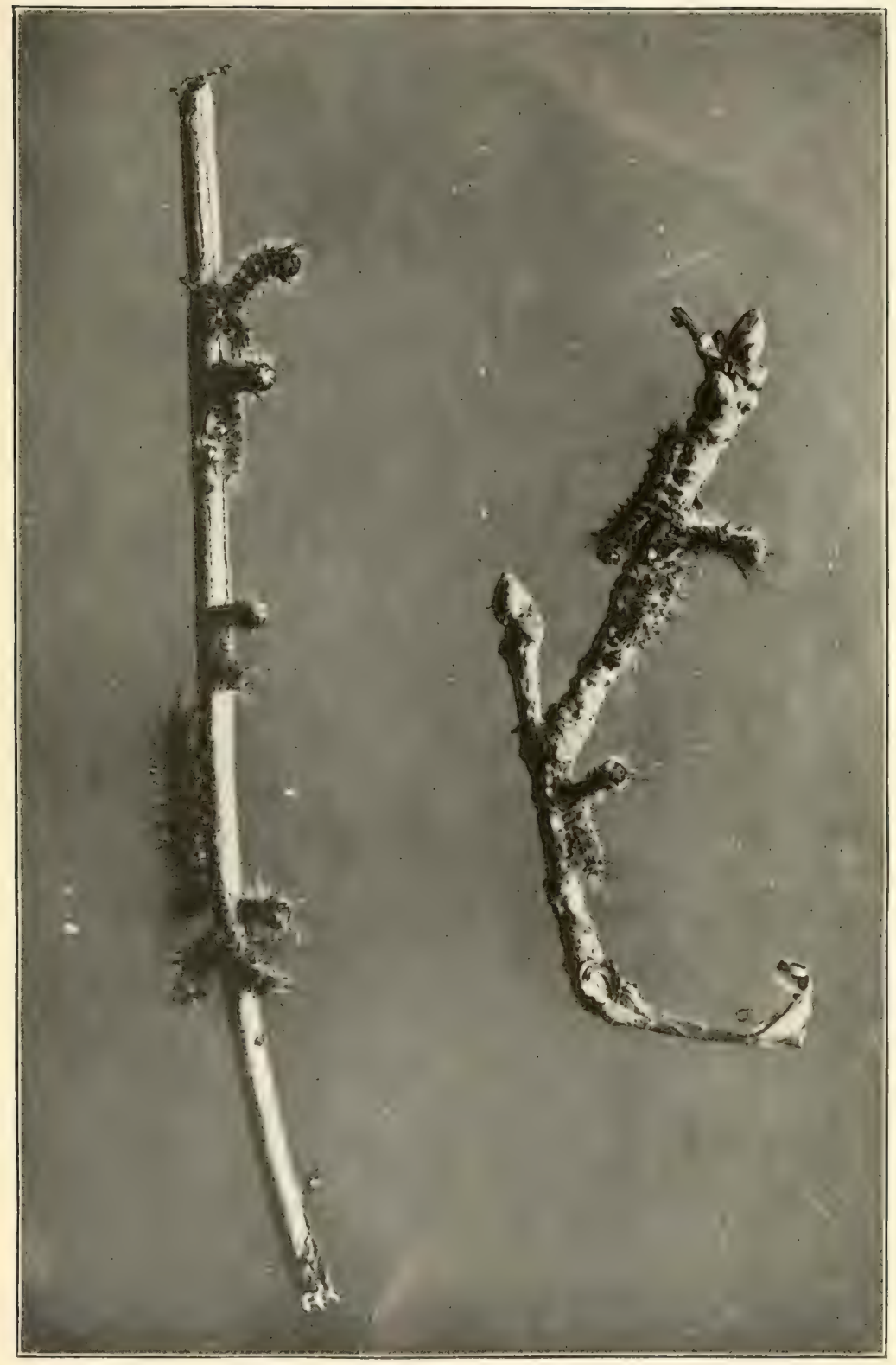

Gypsy caterpillars dead from a disease similar to the brown-tail fungus. Note the characteristic position of the body of the dead caterpillars. 

resting spores formed in 1909 and 1910, except those which must have germinated and the few removed for experiment and examination. The disease appeared on the $23 \mathrm{~d}$ of MIay, when a very small larva broke out with a few feebly growing pustules. On the 27 th a half-grown caterpillar died from the disease in the greenhouse, and again on the 9th of June a large gypsy was found rigid and ready to shoot. From these larvie, and from others which subsequently developed the disease, about 500 caterpillars were directly inoculated, but it was not until the 19th of June that the supply of diseased material warranted the first planting, at Brookline. On the 24th and 26 th of June two other plantings were made in a badly infested scrub oak woodland in Roberts. Careful inspection on the 29th of June, and on the 6th and 15th of July, failed to reveal the slightest sign of the fungus in either of these plantings. The wilt disease appeared to be universally distributed wherever the gypsies were feeding, and was serere enough during the hot weather of the last half of June and of early July to kill off the caterpillars in the rearing boxes and the disease boxes at the garden to such an extent that the propagation of the fungus became more and more difficult, until finally it had to be abandoned, owing to the total destruction of the culture larre.

\section{Conclusions from work on the Gypsy Fungus.}

The experiments with the gypsy fungus, notwithstanding the fact that they were made under unfavorable weather conditions, both in 1910 and 1911, indicate that this disease is not a promising form for artificial use. This conclusion is based not only on the fact that the fungus is itself far more difficult to propagate than that of the brown-tail, and is much more sensitive to unfavorable weather conditions, but is also evident from the fact that the breeding in confinement of gypsy larve is associated with difficulties which are in themselves sufficient to render the continuous propagation of the fungus from month to month or from year to year almost impossible.

Should it obtain a foothold in the field, howerer, it might be expected to prove continuously effective from season to season, owing to its habit of forming resting spores in great abundance, which the experiments have shown are able to survive the New 
England winter, and a very slight increase in virulence, such as often appears in parasitic fungi in successive seasons, might bring about quite different results from those abore reported.

\section{LITERATURE.}

Among some of the more important articles dealing with insect diseases and their practical use the following may be mentioned:-

1855. Сонх, F. Empusa musca und die Trrankheit der Stubenfliegen. Nova Acta Acad. Caes. Leop. Carol. d. Nat., XXV., 301, 1855.

1569. Reichardt. Empusa Aulica. In Bail, Ueber Pilzepizootien in Schriften d. Natur. Ges. Danzig. N. F. Band II., 3, 1869.

1875. Сонм, F. Entomophthora Aulicr. Beit. z. Biol. d. Pflanzen, Band I., Heft VII., 1875.

1882. Nowakowski, L. Entonophthoracere. Report in Bot. Zeit,, $1882,560$.

1ESS. Thaxter, R. The Entomophthorea of the United States. MIem. Boston Soc. Nat. Hist., 4, 133-201, 1888.

Forbes, S. A. On the Present State of our Knowledge concerning Contagious Inseet Diseases. Psyche, Vol. V., 3, JanuaryFebruary, 1888.

1889. GiARD, A. Review of Krassiltschik's "De Insectorum Morbis qui Fungis Parasiticis Efficiuntur." Bul. Sci. de France et de la Belgique, Tome XX., 120-136, 1889.

SNow, F. H. Experiments on Artificial Dissemination of Contagious Diseases among Chinch Bugs. Kansas Academy of Sciences, Vol. XII., Topeka, 1889.

1892. Butsson, M. Le Botrytis tenella. Nouveau Moyen de détruire les Vers Blanes et les Hannetons. Compiegne, Imprimerie Henry Lefebvre, 31 Rue Solferino, 1892.

1893. Giard, A. L'Isaria densa. Bul. Sci. de la France et de la Belgique, Tome XXIV., 1893.

1895. Petrit, R. H. Studies in Artificial Cultures of Entomogenous Fungi. Bul. 97, Cornell University Agri. Exp. Sta., 1895.

1597. Rolfs, P. H. A Fungous Disease of the San José Seale, Sphcerostilbe coccophila Tul., Bul. 41, Florida Agri. Exp. Sta., 1897.

1901. Danrsz, M. J., and Wize, M le Dr. K. De L'utilisation des MIuscardine dans la Lutte avec le Cleonus punctiventris. Libraire Agricole de la Maison Rustique. 26 Rue Jacob, Paris, 1901.

Howard, L. O. Experimental Work with Fungous Diseases of Grasshoppers. U. S. Dept. Agri. Yearbook, 459, 1901. 
1902. Brunaer, L. Killing Destruetive Locusts with Fungous Diseases. U. S. Dept. Agri., Div, of Entomology, Bul. 38, new series, 1902.

1903. Sheldion, J. L. Cultures of Empusa. Journal of Applied Mieroscopy and Laboratory Methods, Vol. VI., No. 3, 22122220, Rochester, N. Y., 1903.

1906. Olive, E. W. Cytological Studies on the Entomophthorece. Bot. Gaz. 41, 192-208, 229-261, 1906.

RidDLE, L. W. Cytology of the Entomophthoracea. American Acad. Arts and Sciences, 42, 10, 1906.

190S. Rolfs, P. H., and Fawcett, H. S. Fungous Diseases of Scale Insects and White-17y. Bul. 94, Florida Agri. Exp. Sta., 1908.

Hitchings, Professor. Note on the Infection Experiment at Kittery Point, Me. Maine Dept. Agri. Bur., III., 20, 1908.

1909. Spraying with Aschersonia. Florida Agri. Exp. Sta. Report for year ending June 30, 1909, 38-41; 1910, 39.

1910. Berger, E. W. White-fly Control. Bul. 103, University of Florida Agri. Exp. Sta., 1910.

Fawcett, H. S. An Important Entomogenous Fungus, E E gerita Webberi. Mycologia, Vol. II., No. 4, July, 1910.

Rorer, J. B. The Green Museardine of Froghoppers. Proc. Agri. Soc. of Trinidad and Tobago, Vol. X., 467-482. Society Paper No. 442, 1910.

1911. Kelly, E. O. G., and Pariss, T. H. Chinch Bug Investigations West of the Mississippi River. U. S. Dept. Agri., Bur. Entomology, Bul. 95, Part III., 40-52, 1911.

Billings, F. H., and Glenn, P. A. Results of the Use of the White-fungus Disease in Kansas. U. S. Dept. Agri., Bur. Entomology, Bul. 107, 1911. 


\section{Explanation of Plate VII.}

FIGs, 1-4.-Typical conidia.

FIGS. 5-7.-Germinating conidia.

FIG. 8. - Secondary conidium produced directly from a primary conidium.

Fig. 9. - Four small hyphal bodies.

FIG. 10.-Group of conidiophores showing four stages, $a, b, c$ and $d$, in the development of the conidium.

FIG. 11. - An abnormal hyphal body, apparently partially encysted.

Figs. 12.17. - Characteristic forms of hyphal bodies prior to and during the formation of resting spores.

FIG. 18. - A mature resting spore.

FIG. 19. - Section through the body of a caterpillar, showing the relation of the conidiophores to the integument. 
PLATE VII.

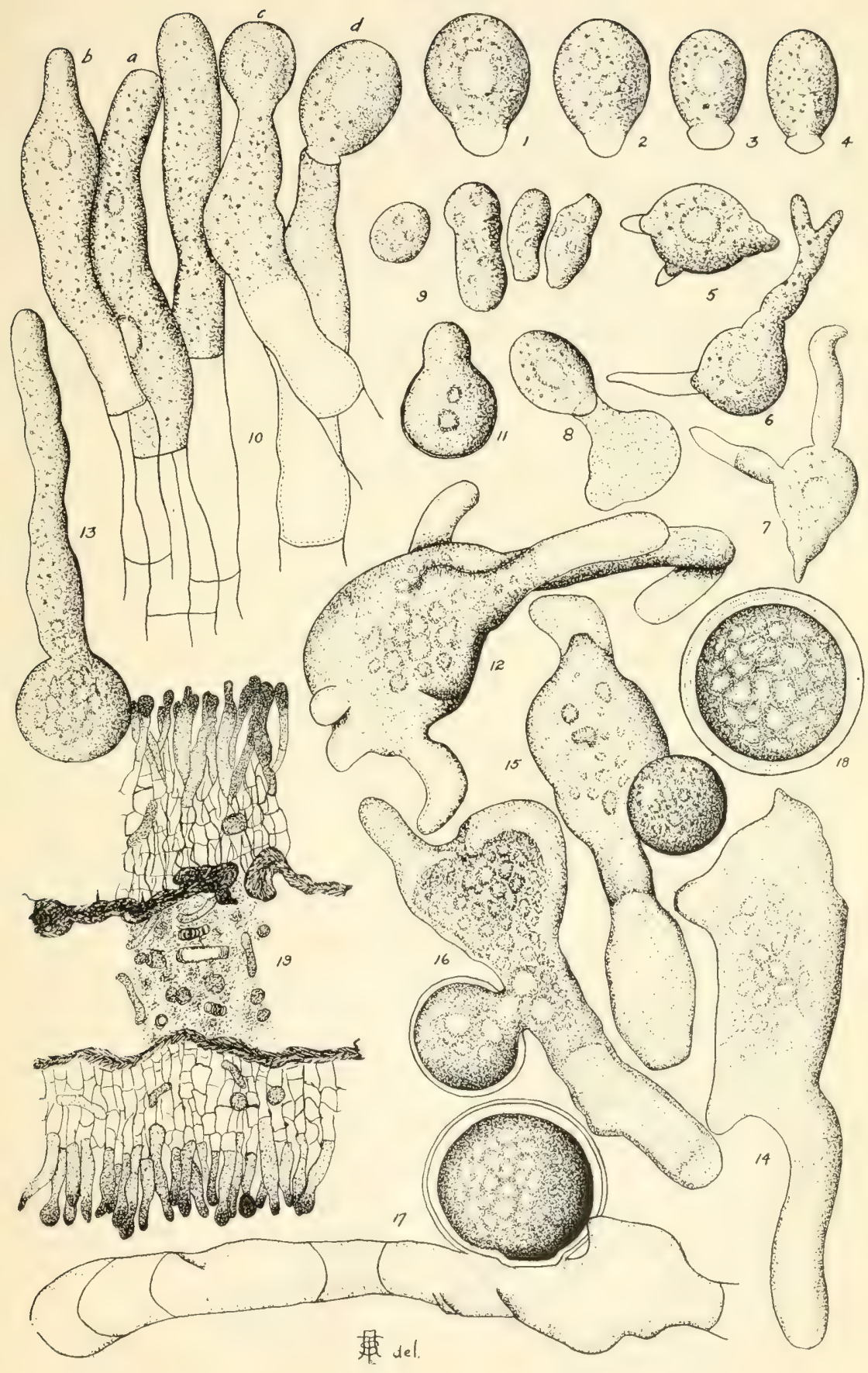


Explanation of Plate VIII.

FIGS. 20-21. - Eneysted hyphal bodies (autumn).

FIGs. 22-23. - Germination of the encysted hyphal bodies.

FIG. 24.-A conidiophore, showing the old walls of primary, secondary and tertiary conidia which have germinated in situ.

FIG. 25. - Pustule of conidiophores which developed from germinating encysted hyphal bodies in a culture dish in the laboratory.

FIG. 26. - Section view of a similar pustule breaking through the integument.

FIG. 27.-Formation of a conidium from the germination of an eneysted hyphal body.

FIGS. 28-31. - Germination of the ordinary type of hyphal bodies.

FIG. 32, - A germinating conidium showing the cross septa $\ell$ which closes the empty tube after the advancing protoplasm.

FIG. 33. - An abuormally large hyphal body.

All the figures were drawn with the aid of the camera lucida, and are reduced about one-third in reproduction. With the exception of Figs. 19, 25, 26 and 27 the magnification wats approximately 425 ; for Fig. 19 the magnification was about 90 ; for Figs. 25 and 26 , about 300 ; and for Fig. 27 , about 600 . 
PLATE VIII

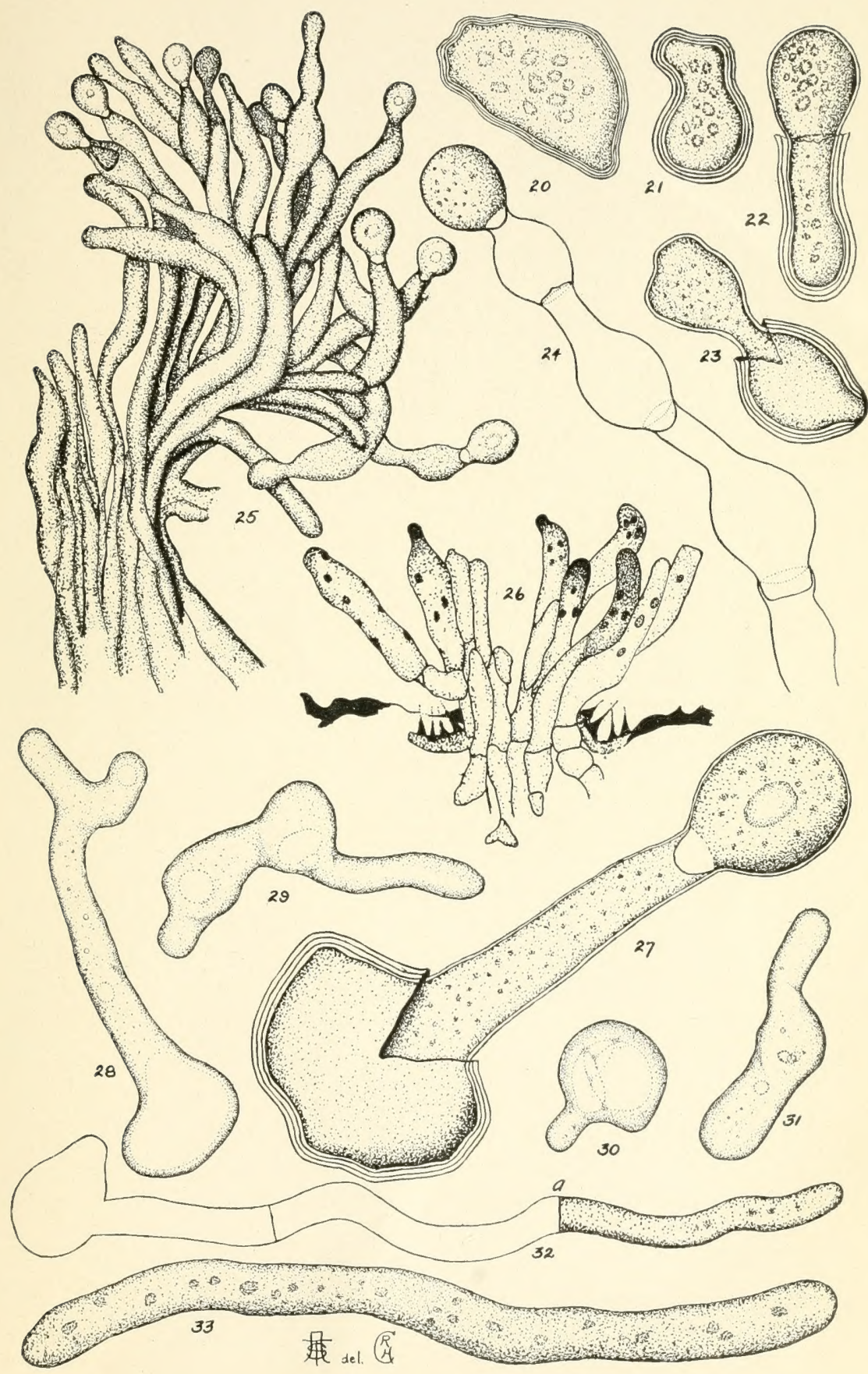



